\title{
Engineering Genetic Resistance against Insects in Japanese Persimmon Using the cryIA(c) Gene of Bacillus thuringiensis
}

\author{
Ryutaro Tao \\ Laboratory of Pomology, Faculty of Agriculture, Kyoto University, Kyoto 606-01, Japan
}

Abhaya M. Dandekar and Sandra L. Uratsu
Department of Pomology, University of California, Davis, CA 95616

Patrick V. Vail and J. Steven Tebbets

Horticultural Crops Research Laboratory, USDA-ARS, 2021 South Peach Avenue, Fresno, CA 93727

AdDITIONAL INDEX wORDs. Agrobacterium-mediated transformation, $\delta$-endotoxins, Diospyros kaki, insecticidal crystal protein, insecticidal crystal protein fragment

\begin{abstract}
Japanese persimmon (Diospyros kaki L. 'Jiro') was transformed using a disarmed strain of Agrobacterium tumefaciens, EHA101, carrying the binary plasmid vector, pDU92.710. The T-DNA region of pDU92.710 contained the kanamycin resistance gene (nptII), the $\beta$-glucuronidase gene (uidA), and a synthetic reconstruct of $\operatorname{cry} \mathrm{IA}(\mathrm{c})$ encoding the insecticidal crystal protein fragment of Bacillus thuringiensis subsp. kurstaki HD-73. Leaf discs made from leaves of shoot cultures were cocultivated with Agrobacterium and cultured on a callus-induction medium containing kanamycin and cefotaxime. Among 720 infected leaf discs, 17 putative transformed callus lines showing kanamycin resistance were obtained after 8 weeks of culture. When these were cultured on a regeneration medium containing kanamycin, 15 formed adventitious buds. Of the 15 shoot lines, 11 grew well on a shoot-proliferation medium containing kanamycin, while 4 lines did not grow well. Of the 11 shoot lines, 10 showed GUS activities by fluorometric assay and were subjected to polymerase chain reaction (PCR) and Southern analyses. Except for two lines, all results were consistent with a stable integration of T-DNA into the persimmon genome. The production of CryIA(c) protein in transformed shoot lines was confirmed with Western analysis using anti-CryIA(c) serum. Insect bioassays were conducted with 10 lines showing GUS activity. Many of these lines showed high significant mortality of the test insects, Plodia interpunctella Hüber and Monema flavescens Walker, when compared to nontransformed controls.
\end{abstract}

Bacillus thuringiensis, a common soil bacterium, produces crystalline inclusion bodies containing one or more insecticidal crystal proteins (ICPs or $\delta$-endotoxins) (Aronson et al., 1986; Höfte and Whiteley, 1989; Whiteley and Schnepf, 1986). Sporecrystal suspensions have been used as biological insecticides in agriculture and forestry for many years (Höfte and Whiteley, 1989). A major limitation of $B$. thuringiensis formulations is their instability and rapid inactivation under field conditions. Recent advances have enabled the development of insect-resistant transgenic plants that express genes encoding ICPs overcoming this limitation.

The first transformed plants with wild-type genes were obtained in tobacco (Nicotiana tabacum) (Vaeck et al., 1987) and tomato (Lycopersicon esculentum) (Fischhoff et al., 1987). Transgenic plants expressed sufficient quantities of ICPs to protect plants from damage caused by tobacco hornworm (Manduca sexta), tobacco budworm (Heliothis virescens), or

Received for publication 23 May 1997. Accepted for publication 12 June 1997. We thank Kevin McBride of Calgene for providing us with a synthetic reconstruct of the $c r y \mathrm{IA}(\mathrm{c})$ and Elizabeth Hood for providing the Agrobacterium strain EHA101. This work was partially supported by a Grant-in-Aid no. 07760029 for Encouragement of Young Scientists to RT from the Ministry of Education, Science, Sports and Culture, Japan. Also, part of this work was supported by JSPS postdoctoral fellowships for research abroad to RT. The cost of publishing this paper was defrayed in part by the payment of page charges. Under postal regulations, this paper therefore must be hereby marked advertisement solely to indicate this fact. tomato hornworm (Manduca quinguemaculata). These species are extremely susceptible to ICPs compared to other host species. In the case of walnut, the level of expression of a wild-type ICP was

Fig. 1. Binary plasmid vector pDU92.710.

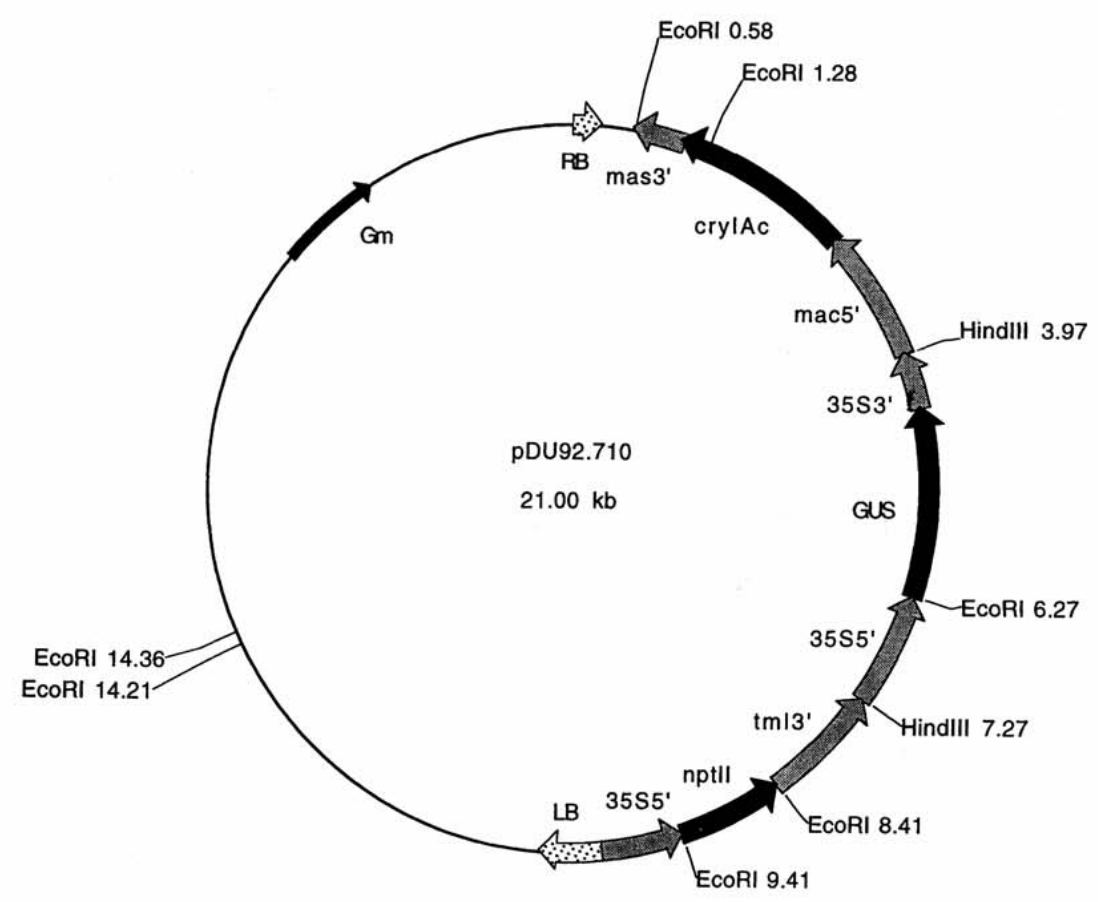


low and insufficient to control a less-susceptible insect pest species (Dandekar et al., 1994). More recently, synthetic genes encoding specific ICPs have been designed to optimize expression in plants and used to transform several crops, such as cotton (Gossypium hirsutum; Perlak et al., 1990), tomato and tobacco (Perlak et al., 1991; Sutton et al., 1992), rice (Oryza sativa; Fujimoto et al., 1993), maize (Zea mays; Koziel et al., 1993), and potato (Solanum tuberosum; Adang et al., 1993). Compared with the wild-type genes, the synthetic genes functioned much better in plants and the levels of expression were increased up to $>500$ times in some of the transformed plants (Perlak et al., 1991).

In this paper, we describe a successful Agrobacterium-mediated transformation of Japanese persimmon (Diospyros kaki) with a synthetic cryIA(c) gene of $B$. thuringiensis. The product of the gene is a $60-\mathrm{kDa}$ N-terminal fragment of the ICP (ICPF) (Adang et al., 1985) that is toxic to lepidopteran insects. Many of the major persimmon insect pests are lepidopteran, such as persimmon fruit moth (Stathmopoda masinissa), persimmon bark borer(Euzophera batangensis), persimmon tree borer (Synanthedon tenuis), and oriental moth (Monema flavescens).

\section{Materials and Methods}

VECTOR CONSTRUCTION FOR THE EXPRESSION OF cryIA(C) GENE. The plasmid vector $\mathrm{pCGN} 4072$ containing a synthetic construct of cryIA(c) was provided by Kevin McBride (Calgene Inc., Davis, Calif.). This plasmid contained a completely resynthesized cryIA(c) gene cassette cloned into the binary vector pCGN1578. The synthetic gene cassette contained the active fragment corresponding to the first 591 amino acids from the $\mathrm{N}$-terminal of cryIA(c) gene from $B$. thuringiensis subsp. kurstaki $\mathrm{HD}-73$ regulated by the mac regulatory sequences (Comai et al., 1990). A modified GUS cassette capable of high and stabilized expression in plants (Fisk, 1996) contained in pRTL2. GUS/SV was introduced into this vector. The GUS cassette was cut with HindIII, ligated to pCGN4072 (similarly digested with HindIII), resulting in the binary vector, pDU92.710 (Fig. 1). pDU92.710 was introduced into a disarmed strain of A. tumefaciens, EHA101 (Hood et al., 1986), as previously described (Holsters et al., 1978) and used for persimmon transformation. EHA101 was selected as a host strain because A281, the wild-type strain of EHA101, has been shown to be very virulent on persimmon (Tao et al., 1995).

Growth AND VIRULENCE INDUCTION OF AGROBACTERIUM. The bacterial strain, EHA101(pDU92.710), was inoculated to $10 \mathrm{~mL}$ of 523 medium (Kado et al, 1972) with $20 \mu \mathrm{g} \cdot \mathrm{mL}^{-1}$ gentamicin and 50 $\mu \mathrm{g} \cdot \mathrm{mL}^{-1}$ kanamycin and grown at $25^{\circ} \mathrm{C}$ overnight. The bacteria were centrifuged at $1500 g_{\mathrm{n}}$ for $20 \mathrm{~min}$ and diluted and resuspended in low $\mathrm{pH}$ (5.2) virulence-induction medium, consisting of MS20 plus $0.1 \mathrm{~mm}$ acetosyringone and $1 \mathrm{~mm}$ betaine phosphate (James et al., 1993) without antibiotics, to give a final $\mathrm{OD}_{420}$ of 0.5 . After dilution, bacterial virulence was induced by incubation at $25^{\circ} \mathrm{C}$ for $5 \mathrm{~h}$ with agitation at $200 \mathrm{rpm}$.

Plant transformation. Leaf discs ( $7 \mathrm{~mm}$ in diameter) were prepared using a cork borer from leaves of shoot cultures subcultured for 6 weeks. Shoot cultures were derived from dormant buds of 'Jiro' and maintained for $>5$ years (Tao and Sugiura, 1992a) on Murashige and Skoog (MS) (1962) medium with $5 \mu \mathrm{m}$ zeatin and $1 \mu \mathrm{M}$ indole butyric acid (IBA), pH 5.7, and solidified with agar powder for microbiological culture medium (Wako Pure Chemicals C. Td., Tokyo). Growth conditions for the shoot cultures were a 16-h light/8-h dark cycle at $28^{\circ} \mathrm{C}$. Light was provided by cool-white fluorescent lamps with a total light intensity of $60 \mu \mathrm{mol} \cdot \mathrm{s}^{-1} \cdot \mathrm{m}^{-2}$. Before Agrobacterium infection, 48 leaf discs/plate $(100 \times 15 \mathrm{~mm})$ were cultured on one-half-strength MS medium (Sugiura et al., 1986) containing $10 \mu \mathrm{M}$ zeatin, $10 \mu \mathrm{M}$ napthalene acetic acid (NAA), pH 5.7, and $0.8 \%(\mathrm{~m} / \mathrm{v})$ agar for $3 \mathrm{~d}$, with growth conditions as described above. After this preinfection they were inoculated by immersion for $15 \mathrm{~min}$ in a low-pH (5.2) virulenceinduction medium containing Agrobacterium inoculum as described earlier (James et al., 1993). After inoculation, leaf discs were blotted briefly on sterile filter paper to remove excess inoculum, deposited on filter paper (Whatman no. 1), and placed on one-half-strength MS medium containing $10 \mu \mathrm{m}$ zeatin, $10 \mu \mathrm{M}$ NAA, pH 5.7, and $0.8 \%(\mathrm{~m} / \mathrm{v})$ agar for cocultivation. Cocultivation was carried out for $3 \mathrm{~d}$ at $28^{\circ} \mathrm{C}$ in the dark. After cocultivation they were transferred to a disinfection medium, which consisted of onehalf-strength MS medium with $10 \mu \mathrm{M}$ zeatin, $10 \mu \mathrm{M}$ NAA, 500
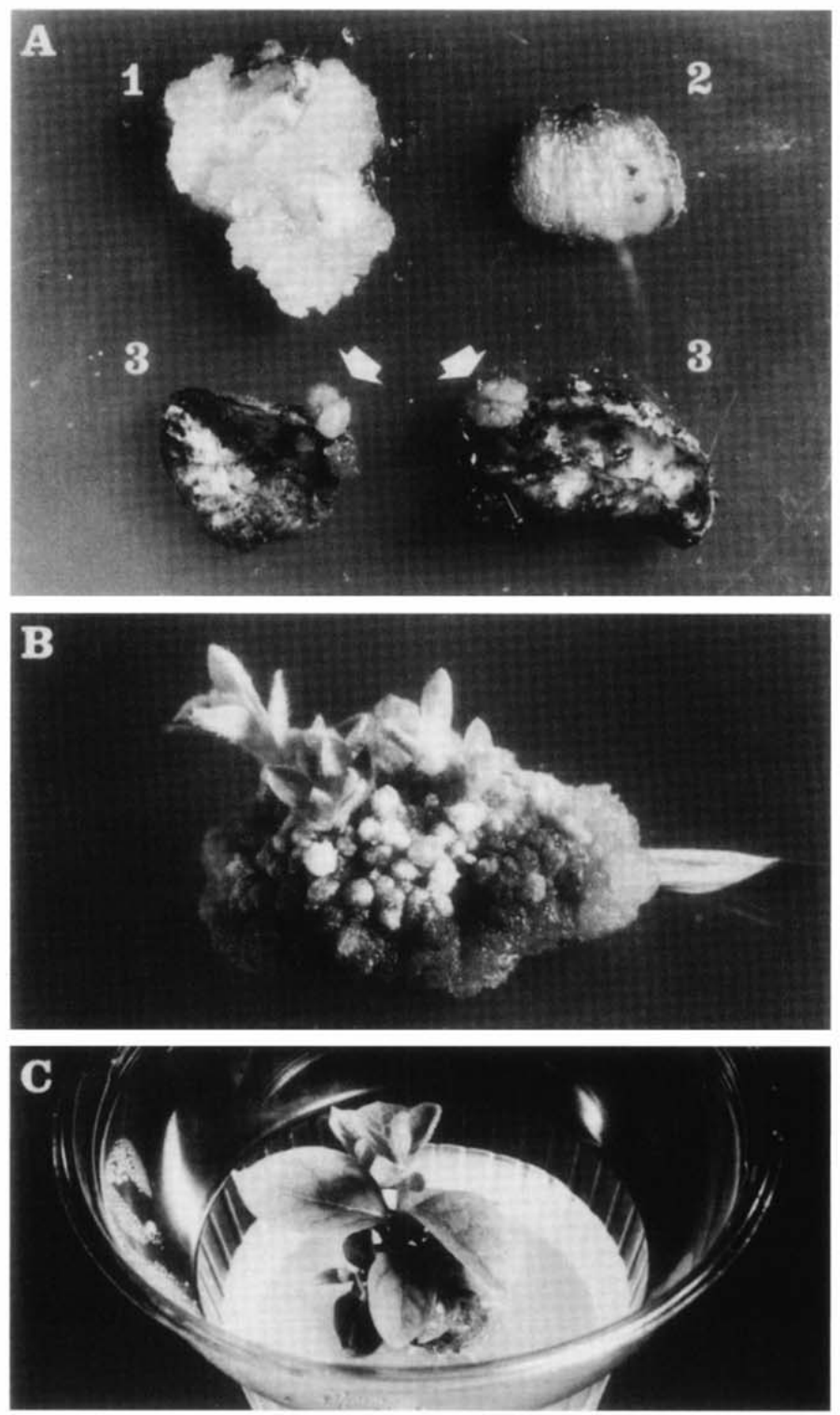

Fig. 2. Regeneration of transformed persimmon cv. Jiro with the synthetic crylA(c) gene of Bacillus thuringiensis. (A) Callus formation from leaf discs after 8 weeks of Agrobacterium inoculation. 1) Control uninoculated leaf disc cultured without kanamycin. 2) Control uninoculated leaf disc cultured with kanamycin. 3) Inoculated leaf discs cultured with kanamycin. Arrows indicate putative transformed calli. (B) Adventitious bud formation from transformed calli after 6 weeks of culture on regeneration medium containing kanamycin. (C) Shoot growth from adventitious bud after 6 weeks on shoot medium with kanamycin. 
$\mu \mathrm{g} \cdot \mathrm{mL}^{-1}$ cefotaxime, $\mathrm{pH} 5.7$, and $0.8 \%(\mathrm{~m} / \mathrm{v})$ agar. At the disinfection stage, the number of leaf discs cultured on a plate was reduced to 24 and the cultures were grown in the dark at $28^{\circ} \mathrm{C}$. After $3 \mathrm{~d}$, the leaf discs were transferred to a selection medium, which consisted of one-half-strength MS medium with $10 \mu \mathrm{m}$ zeatin, 10 $\mu \mathrm{M}$ NAA, $500 \mu \mathrm{g} \cdot \mathrm{mL}^{-1}$ cefotaxime, $50 \mu \mathrm{g} \cdot \mathrm{mL}^{-1}$ kanamycin , $\mathrm{pH}$ 5.7 , and $0.8 \%(\mathrm{~m} / \mathrm{v})$ agar and cultured for 1 week in the dark at 28 ${ }^{\circ} \mathrm{C}$. Then they were transferred to the same fresh medium but with kanamycin increased to $100 \mu \mathrm{g} \cdot \mathrm{mL}^{-1}$ and the number of leaf discs per petri dish was reduced to 12 . Leaf discs were further subcultured to the same fresh medium every 2 weeks. The number of leaf discs per petri dish was occasionally reduced to six depending on the growth of leaf discs. Fifty-five days after inoculation with Agrobacterium, calli that formed from the cut surfaces of leaf discs were removed and cultured on one-half-strength MS medium with $10 \mu \mathrm{m}$ zeatin, $1 \mu_{\mathrm{M}} \mathrm{NAA}, 250 \mu \mathrm{g} \cdot \mathrm{mL}^{-1}$ cefotaxime, $100 \mu \mathrm{g} \cdot \mathrm{mL}^{-1}$ kanamycin, $\mathrm{pH} 5.7$, and $0.8 \%(\mathrm{~m} / \mathrm{v})$ agar in the dark at $28^{\circ} \mathrm{C}$. At this point, each single callus mass was cultured on an individual petri dish $(60 \times 15 \mathrm{~mm})$. After 2 and 4 wecks of culture, the calli were transferred to one-half-strength MS medium with $10 \mu \mathrm{m}$ zeatin, 1 $\mu \mathrm{m}$ indole acetic acid (IAA), $100 \mu \mathrm{g} \cdot \mathrm{mL}^{-1} \mathrm{kanamycin}, \mathrm{pH} 5.7$, and $0.8 \%(\mathrm{~m} / \mathrm{v})$ agar. Thereafter, calli were maintained in the dark at 28 ${ }^{\circ} \mathrm{C}$ by subculturing to the same fresh medium every 6 weeks. After several subcultures, calli were subdivided and transferred to a differentiation medium consisting of MS medium supplemented with $10 \mu \mathrm{m}$ zeatin, $0.1 \mu \mathrm{m}$ IAA, $100 \mu \mathrm{g} \cdot \mathrm{mL}^{-1}$ kanamycin, $\mathrm{pH} 5.7$, and $0.8 \%(\mathrm{~m} / \mathrm{v})$ agar to induce adventitious bud formation (Tao et al., 1991). A single callus mass weighing $\approx 200 \mathrm{mg}$ was placed on the adventitious bud formation medium in a petri dish $(60 \times 15$ $\mathrm{mm}$ ) with a total of five callus masses initiated for each callus line. Once adventitious buds were formed, a vigorous shoot was chosen per callus line and transferred to a shoot proliferation medium and maintained thereafter with continuous subculturing every 6 weeks. Growth conditions for the shoot cultures were a 16-h light/8-h dark cycle at $28^{\circ} \mathrm{C}$. Light was provided by cool-white fluorescent lamps with a total light intensity of $60 \mu \mathrm{mol} \cdot \mathrm{m}^{-2} \cdot \mathrm{s}^{-1}$. For rooting and acclimatization, basal ends of the shoots were treated with $1.5 \mathrm{~mm}$ IBA (50\% aqueous ethanol solution) and cultured as previously reported (Tao and Sugiura, 1992a). For rooting, cultures were kept in the dark at $28^{\circ} \mathrm{C}$ for the first $10 \mathrm{~d}$, followed by $28^{\circ} \mathrm{C}$ under a 12 $\mathrm{h}$ photoperiod with a light intensity of $60 \mu \mathrm{mol} \cdot \mathrm{m}^{2} \cdot \mathrm{s}^{-1}$ provided by cool-white fluorescent lamps. In each experiment, 240 leaf discs were used for inoculation with Agrobacterium and 96 were used as noninoculated controls. One-half of the discs used as noninoculated controls was cultured exactly like inoculated explants whereas the other half was cultured without kanamycin. The experiment was replicated three times, and 1008 leaf discs were used.

Fluorometric DETERMINATION OF GUS ACTIVITY. Fluorometric determination of GUS activity was carried out as previously described (Jefferson, 1987). Leaf discs ( $8 \mathrm{~mm}$ in diameter) were made from unfolded young leaves. A single leaf disc was homogenized with $10 \mathrm{mg}$ of polyvinylpolypyrrolidone(PVP) in $100 \mu \mathrm{L}$ of extraction buffer consisting of $50 \mathrm{~mm}$ sodium phosphate buffer (pH 7) containing $10 \mathrm{~mm}$ EDTA, $10 \mathrm{~mm} 2$-mercaptocthanol, $0.1 \%$ $(\mathrm{m} / \mathrm{v})$ sodium lauryl sarcosine, and $0.1 \%(\mathrm{~m} / \mathrm{v})$ Triton X-100. The homogenate was centrifuged at $12,000 g_{\mathrm{n}}$ for $10 \mathrm{~min}$. The superna-

Table 1. Analysis of transformed persimmons with cryIA(c) gene of Bacillus thuringiensis.

\begin{tabular}{|c|c|c|c|c|c|c|c|}
\hline \multirow[b]{2}{*}{$\operatorname{Line}^{y}$} & \multirow{2}{*}{$\begin{array}{l}\text { Adventitious bud } \\
\text { formation }(\%)^{\mathrm{x}}\end{array}$} & \multirow{2}{*}{$\begin{array}{c}\text { GUS } \\
\text { activityw }\end{array}$} & \multicolumn{3}{|c|}{$\mathrm{PCR}^{\mathrm{x}}$} & \multirow{2}{*}{$\begin{array}{l}\text { No. of T-DNA } \\
\text { integrated }\end{array}$} & \multirow{2}{*}{$\begin{array}{l}\text { Westem blotting } \\
\text { with } c r y \mathrm{IA}(\mathrm{c})^{\mathrm{u}}\end{array}$} \\
\hline & & & $\operatorname{cryIA(c)}$ & GUS & $n p t I I$ & & \\
\hline$\overline{\mathrm{CS}}$ & $\mathrm{ND}^{t}$ & - & - & - & - & 0 & - \\
\hline $\mathrm{CC}$ & 100 & - & - & - & - & 0 & - \\
\hline E1 & 20 & ND & ND & ND & ND & ND & ND \\
\hline E2 & 40 & ++ & + & + & + & 3 & ++ \\
\hline E3 & 40 & t+ & + & + & + & 1 & ++ \\
\hline E4 & 60 & t+ & + & + & + & 1 & ++ \\
\hline E5 & 40 & ++ & + & + & + & 2 & ++ \\
\hline E6 & 60 & ++ & + & + & + & 1 & ++ \\
\hline E7 & 20 & ND & ND & ND & ND & ND & ND \\
\hline E8 & 0 & ND & ND & ND & ND & ND & ND \\
\hline E9 & 40 & ++ & + & + & + & 1 & + \\
\hline E10 & 20 & ND & ND & ND & ND & ND & ND \\
\hline E11 & 40 & + & + & + & + & 2 & + \\
\hline E12 & 80 & - & ND & ND & ND & ND & ND \\
\hline E13 & 40 & ND & ND & ND & ND & ND & ND \\
\hline E14 & 20 & ++ & - & + & + & 2 & - \\
\hline E15 & 60 & ++ & + & + & + & 2 & + \\
\hline E16 & 0 & ND & ND & ND & ND & ND & ND \\
\hline E17 & 80 & ++ & + & + & + & 1 & ++ \\
\hline
\end{tabular}

${ }^{2}$ Expected DNA fragments were amplified (+); not amplified (-).

${ }^{y} \mathrm{CS}=$ nontransformed 'Jiro' shoot line maintained on the shoot medium, $\mathrm{CC}=$ nontransformed 'Jiro' regenerated from callus on the regeneration medium without kanamycin, E = transformed Jiro regenerated from callus on the regeneration medium with kanamycin. E1, E7, E10, and E13 were discarded before GUS activity assay because of poor growth. E12 was discarded before PCR because of it showed no GUS activity.

${ }^{\mathrm{x}} \mathrm{All}$ the data for adventitious bud formation, except for $\mathrm{CC}$, were obtained in the presence of $100 \mathrm{mg} \cdot \mathrm{L}^{-1} \mathrm{kanamycin}$. For CC, adventitious buds were formed without kanamycin.

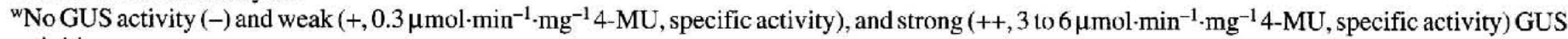
activities.

"Estimated from Southern blotting with $\operatorname{cryIA}(\mathrm{c})$ and $n p t \mathrm{II}$ probes.

"No bands (-) and faint $(+, \approx 0.005 \%$ to $0.01 \%$ of the total soluble protein) and intense $(++,>0.02 \%$ of the total soluble protein) CryIA(c) bands detected. 'Not determined. 
tant was either used directly for a qualitative visual determination of GUS activity or it was diluted 200-fold with the extraction buffer for fluorometric quantitative determination of GUS activity. Ten microliters of the supernatant or diluted supernatant was taken and mixed with $50 \mu \mathrm{L}$ of $4 \mathrm{~mm} 4$-methyl umbellifery-Dglucuronide (MUG) dissolved in the extraction buffer. After incubation at $37^{\circ} \mathrm{C}$ for $20 \mathrm{~min}, 750 \mu \mathrm{L}$ of $0.2 \mathrm{~m}$ sodium carbonate was added to stop the reaction. The presence of GUS activity was evaluated visually by fluorescence with UV light or quantitatively using a fluorometer as described by Jefferson (1987). GUS activity was expressed as micromoles of 4-methylumbelliferone (4-MU) formed per minute per milligram of protein. Three leaf discs were assayed from each shoot line.

Polymerase Chain Reaction (PCR) anAlysis. Total DNA was isolated from leaves of shoot cultures by the method described by Edwards et al. (1991), and cryIA(c), uidA, and $n p t I I$ fragments were identified by PCR. A leaf disc ( $8 \mathrm{~mm}$ in diameter) obtained from shoot culture was crushed with $10 \mathrm{mg}$ of PVP in $400 \mu \mathrm{L}$ of $200 \mathrm{~mm}$ Tris- $\mathrm{HCl}$ buffer ( $\mathrm{pH} 7.5$ ) containing $250 \mathrm{~mm} \mathrm{NaCl}, 25 \mathrm{~mm}$ EDTA, and $0.5 \%(\mathrm{~m} / \mathrm{v})$ SDS. The homogenate was centrifuged at $12,000 g_{\mathrm{n}}$ for $10 \mathrm{~min}$, and $300 \mu \mathrm{L}$ of isopropanol was added to 300 $\mu \mathrm{L}$ of the supernatant. After incubation for $2 \mathrm{~min}$ at room temperature, DNA was recovered by centrifugation and resuspended in $100 \mu \mathrm{L}$ of TE buffer ( $\mathrm{pH} 8$ ). About $100 \mathrm{ng}$ of the DNA were amplified in a total volume of $50 \mu \mathrm{L}$ PCR reaction mixture by 30 cycles of $1 \mathrm{~min}$ at $92^{\circ} \mathrm{C}, 1 \mathrm{~min} 30 \mathrm{~s}$ at $60^{\circ} \mathrm{C}$, and $2 \mathrm{~min}$ at $72^{\circ} \mathrm{C}$. Three sets of oligonucleotide primers were used for the amplification of the fragments of $c r y I A(c)$ (5'-GCGGA TGGAA GGTTG GAGGA GGTT-3' and 5'-CCCGT TACAA CGACT TGACC CGTTT-3'), uidA (5'-GGAAG TGATG GAGCA TCAGG GCGG3 ' and 5'-CGGAC GGGTA TCCGG TTCGT TGGC-3'), and $n p t$ II (5'-ATGAT TGAAC AAGAT GGATT GCACG CA-3' and 5'GAAGA ACTCG TCAAG AAGGC GATAG A-3'). Reagents and protocols for PCR were from Perkin Elmer. PCR analysis was performed twice for each shoot line.

SouthERN ANALYSIS. Total DNA was isolated from leaves of shoot cultures by an SDS method (Dellaporta et al., 1983). One gram of leaf tissue was frozen in liquid nitrogen and ground to a fine powder using a mortar and pestle containing $0.2 \mathrm{~g}$ PVP. The tissue was added to $15 \mathrm{~mL}$ of extraction buffer $(0.1 \mathrm{M}$ Tris- $\mathrm{HCl}(\mathrm{pH}$ 8) containing $50 \mathrm{~mm}$ EDTA, $500 \mathrm{~mm} \mathrm{NaCl}$, and $10 \mathrm{~mm} 2$ mercaptoethanol) and $1 \mathrm{~mL}$ of $20 \%(\mathrm{~m} / \mathrm{v})$ SDS was added and incubated at $65^{\circ} \mathrm{C}$ for $10 \mathrm{~min}$. Then $5 \mathrm{~mL}$ of $5 \mathrm{~m}$ potassium acetate (pH 5.2) was added, incubated on ice for $20 \mathrm{~min}$, and centrifuged at $12,000 \mathrm{~g}_{\mathrm{n}}$ for $20 \mathrm{~min}$. The supernatant was filtered through a layer of Miracloth (Chicopee Mills Inc.) and $10 \mathrm{~mL}$ of isopropanol $(100 \%)$ was added to the supernatant, incubated at $-20^{\circ} \mathrm{C}$ for 30 min, and centrifuged at $12,000 g_{\mathrm{n}}$ for $15 \mathrm{~min}$. Pellets were redissolved in $0.7 \mathrm{~mL}$ of $50 \mathrm{~mm}$ Tris- $\mathrm{HCl}(\mathrm{pH} 8)$ containing $10 \mathrm{~mm}$ EDTA and centrifuged at $10,000 g_{\mathrm{n}}$ for $10 \mathrm{~min}$ to remove debris. Seventy-five microliters of $3 \mathrm{~m}$ sodium acetate $(\mathrm{pH} 5.2)$ and $500 \mu \mathrm{L}$ of isopropanol were added to the supernatant to recover DNA. After centrifugation at $10,000 g_{\mathrm{n}}$ for $5 \mathrm{~min}$, the DNA pellet was washed twice with $80 \%$ ethanol and dissolved in $75 \mu \mathrm{L}$ TE buffer. About $8 \mu \mathrm{g}$ of DNA was digested with HindIII, and Southern blots were prepared as previously described (Dandekar et al., 1988). CryIA(c), uidA, and $n p t I I$ probes containing structural sequences digested from plasmid DNA were labeled by random primer incorporation of dUTP linked to DIG-dUTP. Immunological detection of the hybridization was carried out using anti-DIGalkaline phosphatase conjugate and chemiluminescent substrate Lumi-Phos 530 (Boehringer Mannheim). Chemiluminescence was documented on X-ray films. Reagents and protocols for DNA labeling and immunological detection of DIG-dUTP were obtained from Boehringer Mannheim. Southern analysis was performed once for each shoot line.

WeSTERN BLOTting. Eight leaf discs ( $8 \mathrm{~mm}$ in diameter) were ground with an ice-cold mortar and pestle with $10 \mathrm{mg}$ of PVP in $200 \mu \mathrm{L}$ of sodium phosphate buffer ( $\mathrm{pH} 6.8$ ) containing $150 \mathrm{~mm}$ $\mathrm{NaCl}, 10 \mathrm{~mm}$ EDTA, $10 \mathrm{~mm}$ DTT, $0.3 \%$ (v/v) Tween 20 , and $0.05 \%$ (v/v) Triton X100. The homogenate was centrifuged at $15,000 g_{n}$ for $20 \mathrm{~min}$. Protein content of the supernatant was determined by the Bradford (1976) method. Five parts of the supernatant were mixed with one part of sample buffer, which consisted of $0.35 \mathrm{M}$ Tris- $\mathrm{HCl}(\mathrm{pH} 6.8)$ containing $10 \%(\mathrm{~m} / \mathrm{v})$ SDS, $36 \%$ (v/v) glycerol, $0.6 \mathrm{~m} \mathrm{DTT}, 0.012 \%(\mathrm{~m} / \mathrm{v}) \mathrm{BPB}$, boiled for $5 \mathrm{~min}$, and then $25 \mu \mathrm{g}$ of total protein of each sample were subjected to electrophoresis on a $12 \%$ SDS polyacrylamide gel. After electrophoresis, protein bands were electrophoretically transferred to a nitrocellulose membrane as described by Towbin et al. (1979) for Western blot analysis. CryIA(c) protein was detected immunologically using rabbit anti-CryIA(c) serum prepared against purified $\operatorname{CryIA}(\mathrm{c})$ and was provided to us by $\mathrm{K}$. McBride. The primary antibodies were visualized using anti-rabbit serum with alkaline phosphatase (Promega, Protoblot Western Blot AP system). Western blot analysis was performed twice for each shoot line. The amount of protein was estimated from the stained blots using a computerized image analysis software (Alpha Innotec, Calif.).

INSECT FEEDING ASSAY. We first used the Indianmeal moth (IMM), Plodia interpunctella Hübner, a pest of stored products worldwide because IMM is quite susceptible to ICPF (Vail et al., 1991) and is readily available in California where host insect species of persimmon do not occur. Then, oriental moth (OM), a natural insect pest of persimmon, was used to evaluate further the shoot lines showing high levels of IMM mortality. For IMM feeding assay, completely unfolded leaves were harvested from 10 independent lines, immediately frozen in liquid $\mathrm{N}_{2}$, and lyophilized. IMM feeding assays were done by homogenizing lyophilized leaves ( $20 \mathrm{mg}$ dry mass) for $1 \mathrm{~min}$ in $9.8 \mathrm{~mL} 100 \mathrm{~mm}$ sodium carbonate buffer ( $\mathrm{pH}$ 10) using a Polytron at medium speed. Fifty microliters of this homogenate was applied to the

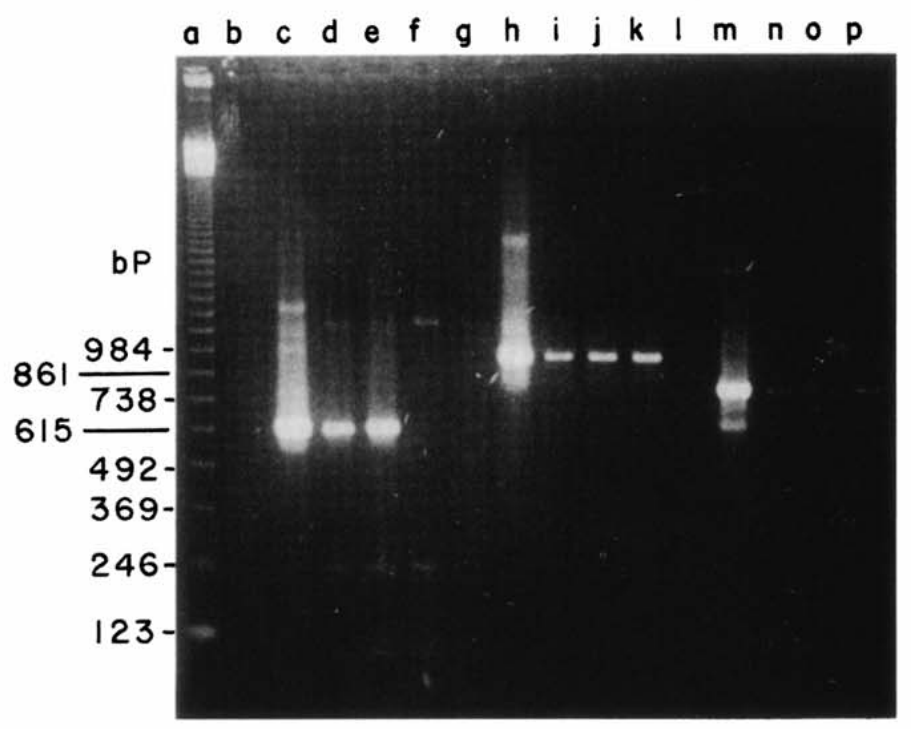

Fig. 3. PCR amplification of $\operatorname{cryIA}(\mathrm{c})$ (Lanes b-f), uidA (Lanes g-k), and nptII (Lanes 1-p) fragments. Lane a: DNA size marker. Lanes b, g, and l: Control nontransformed shoot line used for making leaf discs. Lanes c, h, and m: pDU92.710. Lanes d, i, and n: E3. Lanes e, j, and o: E11. Lanes f, k, and p: E14. 
surface $\left(1 \mathrm{~cm}^{2}\right)$ of 1-mL agar insect diet (BIOSERV no. 9370) in a 2 -mL plastic vial and allowed to air dry for $\approx 1$ to $2 \mathrm{~h}$. Each vial was infested with a single first-instar IMM, closed with a plastic snap lid, and held at $27^{\circ} \mathrm{C}$. After $7 \mathrm{~d}$, the test was evaluated for larval mortality and development. This method resulted in exposure of the feeding insects to a level of ICPF $\approx 5$ times less than the level occurring in fresh leaves before lyophilization and homogenization. The IMM feeding assay was conducted with lyophilized leaves from the 10 shoot lines showing GUS activity. Two different nontransformed shoot lines were included as controls as well as two blank controls (water only and buffer only). Each replication consisted of 30 IMM larvae for each shoot line and the controls. The assays were replicated twice over time for a total of 60 larvae/line observed, except for the buffer control, which was inadvertently duplicated resulting in a total of 120 larvae tested.

The OM feeding assay involved two transformed persimmon lines, which showed high IMM mortality, and one control (nontransformed) line. Fully unfolded mature leaves from potted plants ( $\approx 6$ months old) were put on a layer of filter paper soaked with distilled water and placed in a petri dish $(90 \mathrm{~mm}$ in diameter and $20 \mathrm{~mm}$ in depth). Ten first-instar OM larvae were introduced into a petri dish and held at $20^{\circ} \mathrm{C}$. After $7 \mathrm{~d}$, the test was evaluated for larval mortality and leaf area consumed by OM larvae. Fifteen leaves were evaluated for each line. The insect mortality and development data were analyzed using chi-square test and ANOVA with Bonferroni means separation option using the Statistical Analysis System (SAS) program (SAS Inst., Cary, N.C.).

\section{Results}

CONSTRUCTION OF PDU92.710. A map of pDU92.710 is shown in Fig. 1. The cryIA(c) gene sequence is regulated by mac, a previously described chimeric plant promoter that combines elements from the CaMV35S and mas promoters (Comai et al., 1990). The selectable marker gene encoding kanamycin resistance and the binary plasmid backbone were derived from the previously described vector pCGN1578 (McBride and Summerfelt, 1990). The GUS cassette contained in this vector contains modifications that improve its translation and stability of the GUS protein in plant cells (Fisk, 1996).

TrANSFORMATION OF PERSIMMON. Vigorous calli were induced from the leaf discs cultured on the medium without kanamycin, and all the leaf discs were completely covered with the calli after 8 weeks of culture (Fig. 2A-1), while no callus was formed from the control leaf discs cultured on the medium containing kanamycin (Fig. 2A-2). Of the 720 infected leaf discs, a total of 17 putative transformed callus lines showing kanamycin resistance were obtained (Fig. 2A-3); i.e., five each from replications 1 (E1-5) and 2 (E6-10) and seven from replication 3 (E11-17) (Table 1). All the control calli cultured on the medium without kanamycin formed adventitious buds, whereas only $20 \%$ of the control calli formed buds on the medium with kanamaycin. No further growth of the adventitious buds induced from the control calli was observed on the shoot medium with kanamycin. Of the 17 putative transformed callus lines, 15 formed adventitious buds on the regeneration medium containing kanamycin, with adventitious bud formation percentages ranging from $20 \%$ to $80 \%$ (Fig. 2B, Table 1). Of the 15 shoot lines, 11 grew well on the shoot proliferation medium con- taining kanamycin (Fig. 2C) and were assayed for GUS activity, while, 4 lines did not. Among these, 10 lines showed GUS activity, while nontransformed shoots and one putative transformant showed no GUS activity. GUS activities (4-MU, protein basis) of all lines, except for one (E11), were strong, and ranged from 3.3 to 5.9 $\mu \mathrm{mol} \cdot \mathrm{min}^{-1} \cdot \mathrm{mg}^{-1} 4-\mathrm{MU}$, specific activity. E11 showed a relatively low GUS activity of $0.3 \mu \mathrm{mol} \cdot \mathrm{min}^{-1} \cdot \mathrm{mg}^{-1} 4-\mathrm{MU}$, specific activity. For further study, we selected the 10 shoot lines having GUS activity (E2, 3, 4, 5, 6, 9, 11, 14, 15, and 17) and two nontransformed control shoot lines. One was the shoot line used to obtain leaf discs (CS), and the other was the shoot line regenerated from the calli induced from the leaf disc (CC) (Table 1).

DNA ANALYSIS. The presence of the T-DNA was first confirmed by PCR. All putative transformed lines, except for E14, showed expected PCR products of 949,625 , and $792 \mathrm{bp}$, respectively, for uidA, cryIA(c), and $n p t I I$ fragments (Fig. 3, Table 1). No amplification was observed for the DNA prepared from nontransformed shoot lines, CS and CC. With E14, the authentic PCR products for uid $\mathrm{A}$ and $n p t \Pi$ could be seen, while no PCR amplification occurred for the fragment of cryIA(c). To examine internal T-DNA fragments and to determine the copy number of T-DNA inserted into the persimmon genome, DNA obtained from individual shoot lines was digested with HindIII, and Southern analysis was performed using $u i d \mathrm{~A}$, cryI $\mathrm{I}(\mathrm{c}), n p t \mathrm{II}$ probes and expected fragment sizes are shown in Fig. 4. Hybridization with the uidA probe revealed internal 3300-bp fragments. Hybridization of the same blots with the $\operatorname{cryIA}(\mathrm{c})$ probe revealed the fragments $>3974 \mathrm{bp}$, which were due to hybridization of the $c r y \mathrm{IA}$ (c) sequence adjacent to the right border. Hybridization of the same blots with the nptII probe, which also detected sequences adjacent to the left border, was used to further confirm the number of T-DNAs integrated into the persimmon genome. All the data, except for E11 (Fig. 4 lane c) and E14 (Fig. 4 lane d), were consistent with the integration of individual T-DNAs into the persimmon genome (Fig. 4). Based on the

Fig. 4. Southern blot analysis of persimmon genomic DNA digested with HindIII showing the pattern of hybridization with three different probes. A physical map of the T-DNA digested with HindIII is illustrated below. Lane a: control nontransformed shoot line used for making leaf discs. Lane b: E9. Lane c: E11. Lane d: E14. Lane e: E15. Lane f: E17.

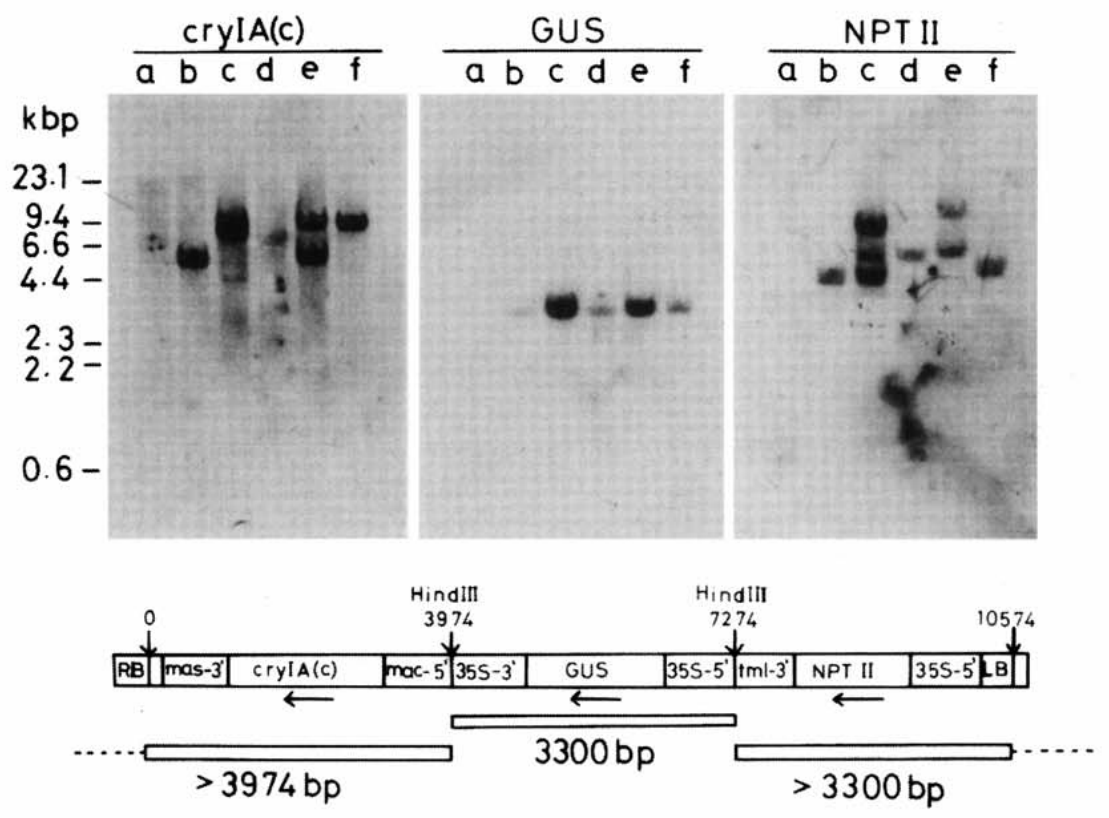




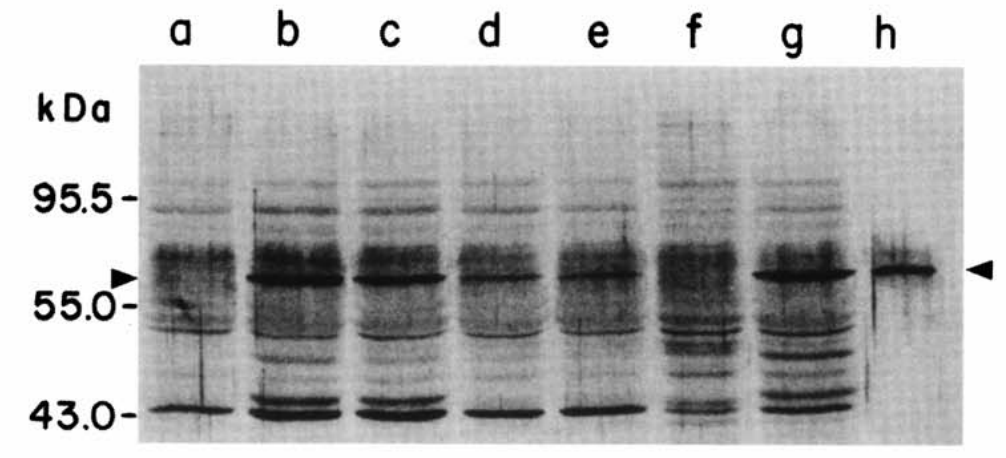

ing on the shoot lines, we could estimate that $>0.02 \%$ of the total soluble protein was CryIA(c) protein in the shoot lines, $\mathrm{E} 2,3,4,5,6$, and 17 . Lesser amounts $(0.005 \%$ to $0.01 \%$ of the total soluble protein) could be detected in the other three lines, E9, 11, and 15.

INSECT FEEDING ASSAY. Compared to the nontransformed shoot line, significantly higher IMM mortality was observed with all of the transformed shoot lines (Table 2), except E14, which also produced no detectable band at $60 \mathrm{kDa}$ (Table 1). The shoot lines producing the highest mortality were E2, E3, E5, and particularly E17 (Table 2). These lines were also among those producing intense bands at $60 \mathrm{kDa}$ (indicated by ++ , Table 1). Furthermore, these shoot lines and E4, E6, and E9 significantly slowed larval development as indicated

Fig. 5. Western blot of total leaf proteins of persimmon separated on $12 \%$ SDSPAGE and probed with rabbit anti-CryIA(c) antibody. Arrows indicate the position of the CryIA(c) ICPF band. Lane a: Control nontransformed shoot line used for making leaf discs. Lane b: E2. Lane c: E3. Lane d: E9. Lane e: E11. Lane f: E14. Lane g: E17. Lane h: Pure CryIA(c) ICPF $10 \mathrm{ng}$.

number of the bands hybridized to $\operatorname{cryIA}(\mathrm{c})$ and $n p t \mathrm{II}$ probes, the number of T-DNA copies incorporated into the persimmon genome was estimated to be between one and three (Table 1). As expected, no hybridization signal was detected in the nontransformed control shoot lines, CS and CC. With E11, the results obtained by the hybridization with the cryIA(c) and nptII probes indicates the insertion of two T-DNAs in one location, since two bands were detected with the $n p t I I$ probe, while only one band with the cryIA(c) probe. Similarly in the case of E14, two bands are observed with the cryIA(c) probe and only one band of hybridization with the $n p t I I$ probe. The band intensity in Fig. 4 lanes $\mathrm{c}$ and $\mathrm{e}$ is higher than those in the other lanes (lanes b, d, and f) obtained with uidA probe encoding GUS.

IMMUNODETECTION OF CryiA(c) PROTEIN. A distinct band could be detected at $60 \mathrm{kDa}$ in all the transformed shoot lines, except for E14 (Fig. 5, Table 1). No reactions at $60 \mathrm{kDa}$ were observed with nontransformed shoot lines (Fig. 5 lane a) and E14 (Fig. 5 lane f). Although the amount of CryIA(c) protein produced varied depend- by low mean instars after $7 \mathrm{~d}$ of feeding (Table 2). As IMM is a nonhost insect of persimmon, we selected two transformed strains (E2 and E17), which showed the highest IMM mortality for testing with a pest species of persimmon. These lines were acclimatized, transferred to pots in the greenhouse, and the leaves from these plants were harvested for bioassay using OM that naturally feeds on persimmon leaves. We observed that the E2 and E17 plants grew as well as nontransformed control plants in the greenhouse (Fig. 6) and showed significantly higher level of OM mortality as compared with the control nontransformed plants (CS). The transformed plants E2 and E17 showed a high level of mortality toward OM larvae, $96.7 \pm 1.8$ and $98.0 \pm 1.9$, respectively, compared to the control $(15 \pm 3.9)$. Significant differences could also be observed for the amount of feeding on the leaves (Fig. 6) with the total leaf area consumed by the control at $6.3 \pm 1.5 \mathrm{~cm}^{2}$ compared to $0.2 \mathrm{~cm}^{2}$ for E2 and E17.

\section{Discussion}

In this study, we have developed an Agrobacterium-mediated transformation system for Japanese persimmon and successfully integrated the cryIA(c) gene of $B$. thuringiensis into the persimmon genome. Although transformation with wild-type strains of $A$. tumefaciens (Tao et al., 1995) and A. rhizogenes (Tao et al., 1994)

Table 2. Resistance against Indianmeal moth larvae in transformed persimmons with cryIA(c) gene of Bacillus thuringiensis.

\begin{tabular}{|c|c|c|c|c|c|c|c|c|}
\hline \multirow{2}{*}{\multicolumn{2}{|c|}{$\begin{array}{c}\text { Mortality } \\
(\%)\end{array}$}} & \multirow[b]{2}{*}{ (n) } & \multicolumn{5}{|c|}{ No. of live by instar } & \multirow{2}{*}{$\begin{array}{l}\text { Mean } \\
\text { instar }^{y}\end{array}$} \\
\hline & & & L1 & $\mathrm{L} 2$ & L3 & $\mathrm{L} 4$ & L5 & \\
\hline Water & $6.7 \mathrm{ab}^{\mathrm{x}}$ & $(60)$ & 0 & 0 & 0 & 5 & 51 & $4.9 \mathrm{a}^{\mathrm{w}}$ \\
\hline Buffer & $11.7 \mathrm{ab}$ & $(120)$ & 0 & 0 & 34 & 71 & 1 & $3.7 \mathrm{~b}$ \\
\hline $\mathrm{CS}$ & $11.7 \mathrm{ab}$ & $(60)$ & 0 & 7 & 18 & 28 & 0 & $3.4 \mathrm{~b}$ \\
\hline $\mathrm{CC}$ & $3.3 \mathrm{a}$ & (60) & 0 & 4 & 15 & 39 & 0 & $3.6 \mathrm{~b}$ \\
\hline E2 & $43.3 \mathrm{de}$ & $(60)$ & 3 & 28 & 3 & 0 & 0 & $2.0 \mathrm{efg}$ \\
\hline E3 & $38.3 \mathrm{~d}$ & (60) & 4 & 23 & 10 & 0 & 0 & $2.2 \mathrm{efg}$ \\
\hline E4 & $28.3 \mathrm{~cd}$ & (60) & 2 & 29 & 12 & 0 & 0 & $2.2 \mathrm{defg}$ \\
\hline E5 & $41.7 \mathrm{de}$ & (60) & 4 & 26 & 4 & 1 & 0 & $2.1 \mathrm{efg}$ \\
\hline E6 & $30.0 \mathrm{~cd}$ & $(60)$ & 2 & 31 & 8 & 1 & 0 & $2.2 \mathrm{efg}$ \\
\hline E9 & $28.3 \mathrm{~cd}$ & (60) & 1 & 20 & 21 & 0 & 0 & 2.5 cdefg \\
\hline E11 & $33.3 \mathrm{~cd}$ & (60) & 6 & 11 & 12 & 11 & 0 & 2.7 cdef \\
\hline E14 & $18.3 \mathrm{bc}$ & (60) & 0 & 9 & 10 & 30 & 0 & $3.4 \mathrm{~b}$ \\
\hline E15 & $36.7 \mathrm{~d}$ & (60) & 3 & 11 & 13 & 11 & 0 & $2.8 \mathrm{cde}$ \\
\hline E17 & $55.0 \mathrm{e}$ & (60) & 16 & 11 & 0 & 0 & 0 & $1.4 \mathrm{~h}$ \\
\hline
\end{tabular}

${ }^{2}$ Water $=$ water control, CS = nontransformed 'Jiro' shoot line maintained on the shoot medium, CC $=$ nontransformed 'Jiro' shoot line regenerated from callus on the regeneration medium without kanamycin, $\mathrm{E}=$ transformed 'Jiro' shoot line regenerated from callus on the regeneration medium with kanamycin.

${ }^{\mathrm{y}}$ Mean instar of live larvae.

${ }^{\mathrm{x}}$ Mean separation within column by $\chi^{2}$ test $(p \leq 0.05)$.

${ }^{w}$ Mean separation within column by ANOVA with Bonferroni option $(p \leq 0.05)$. 
Fig. 6. Potted 6-monthold transformed persimmons with the cryIA(c) gene of Bacillus thuringiensis (E2 and E17) and the control nontransformed plant (CS)(upper photograph). Appearance of the leaves from the CS, E2, and E17 plants after $7 \mathrm{~d}$ of feeding with oriental moth larvae (lower photograph).

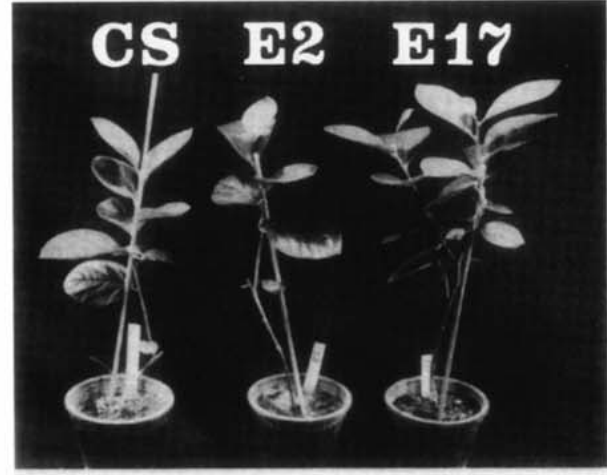

has been reported in persimmon, this is the first report describing transformation of this fruit species with a disarmed strain of Agrobacterium carrying a binary plasmid vector that has the genes of horticultural interest and for selection and screening of transformants. The technique would open the door for the rapid cultivar improvement in Japanese persimmon.

For our leaf disc transformation system, a callus intermediate stage was indispensable to obtain transformants. Earlier work on persimmon has shown that it is difficult to obtain adventitious bud formation directly from leaf discs, and by contrast, a very efficient regeneration system was possible using callus cultures of persimmon (Tamura et al., 1992; Tao et al., 1991; Tao and Sugiura, $1992 b)$. The major drawback of using a callus intermediate is that it takes longer for the regeneration process, and there is a risk of somaclonal variation. The latter will be evaluated when these transgenic plants are introduced into the environment for field testing. The efficiency of the transformants obtained was low, $\approx 1.5 \%$ on a per explant basis. This suggests that a higher number of explants needs to be used initially to ensure a significant number of transformed shoots. There might be some possibilities of improving the efficacy of the transformation system by refining the culture methods and conditions during and after Agrobacterium infection.

Southern analysis revealed that the number of T-DNA copies integrated into the persimmon genome was one to three (Table 1). Although a negative correlation between the number of T-DNA incorporated and its expression level has been suggested to occur (Flavell, 1994; Hobbs et al., 1990; Palauqui and Vaucheret, 1995), no relation was observed in this study between the number of TDNA and the amount of CryIA(c) protein estimated from Western analysis or from mortality obtained with the insect-feeding assay. Usually the level of expression of foreign genes varies widely among transformants with a single copy of T-DNA, even in a single experiment, due to gene-silencing phenomena and methylation or rearrangements of the integrated T-DNA. The effect of copy number might have been obscured by other effects in a study with small sample size, such as the 10 individual transformants tested in this experiment.

With the IMM feeding assay, significantly higher mortalities compared to controls were observed in all transformed lines, except for E14, with mortalities ranging from $18.3 \%$ to $55.0 \%$ (Table 2). There are a few factors that may have contributed to these low mortalities.

1) The CryIA(c) protein produced might have been degraded during lyophilization or subsequent extraction procedures.

2) Some unknown substances in the persimmon leaves might have interacted with CryIA(c) protein and reduced its insectkilling activity. The toxicity of ICP has been reported to be altered (both reduced and stimulated) by plant natural products such as chlorogenic acid and polyphenol oxidase (Ludlum et al., 1991), and protease inhibitor (MacIntosh et al., 1990)

3) The level of ICPF in the lyophilized leaves was diluted 5-fold during the homogenization process $(20 \mathrm{mg}$ dry mass in $9.8 \mathrm{~mL}$ buffer) and the amount of CryIA(c) protein ingested by the IMM larvae was reduced below effective levels. As the results of IMM assay were obtained with a nonhost insect species we further evaluated two transformed lines using OM, a native insect pest of persimmon to confirm efficacy of our transformed lines. The data strongly indicated that levels of ICPF needed to be effective against native insect pest species were obtained in our transformed Japanese persimmon lines.

\section{Literature Cited}

Adang, M.J., M.J. Staver, T.A. Rocheleau, J. Leighton, R.F. Barker, and D.V. Thompson. 1985. Characterized full-length and truncated plasmid clones of the crystal protein of Bacillus thuringiensis subsp. kurstaki HD-73 and their toxicity to Manduca sexta. Gene 36:289-300.

Adang, M.J., M.S. Brody, G. Cardineau, N. Eagan, R.T. Roush, C.K. Shewmarker, A. Jonew, J.V. Oakes, and K.E. McBride. 1993. The reconstruction and expression of a Bacillus thuringiensis cryIIIA gene in protoplasts and potato plants. Plant Mol. Biol. 21:1131-1145.

Aronson, A.I., W. Beckman, and P. Dunn. 1986. Bacillus thuringiensis and related insect pathogens. Microbiol. Rev. 50:1-24.

Bradford, M.M. 1976. A rapid and sensitive method for the quantification of microgram quantities of protein utilizing the principle of protein dye binding. Anal. Biochem. 72:248-254.

Comai, L., P. Moran, and D. Maslyar. 1990. Novel and useful properties of a chimeric plant promoter combining CaMV $35 \mathrm{~S}$ and MAS elements. Plant Mol. Biol. 15:373-381.

Dandekar, A.M., L.A. Martin, and G.H. McGranahan. 1988. Genetic transformation and foreign gene expression in walnut tissue. J. Amer. Soc. Hort. Sci. 113:945-949.

Dandekar, A.M., G.H. McGranahan, P.V. Vail, S.L. Uratsu, C. Leslie, and J.S. Tebbets. 1994. Low levels of expression of wild type Bacillus thuringiensis var kurstaki cryIA(c) sequence in transgenic walnut somatic embryos. Plant Sci. 96:151-162.

Dellaporta, S.L., J. Wood, and J.B. Hicks. 1983. A plant DNA minipreparation: Version II. Plant Mol. Biol. Rpt. 1:19.

Edwards, K., C. Johnstone, and C. Thompson. 1991. A simple and rapid method for the preparation of plant genomic DNA for PCR analysis. Nucl. Acids Res. 19:1349.

Fischhoff, D.A., K.S. Bowdisch, F.J. Perlak, P.G. Marrone, S.H. McCormick, J.G. Niedermeyer, D.A. Dean, K. Kusano-Kretzmer, E.J. Mayer, D.E. Rochester, S.G. Rogers, and R.T. Fraley. 1987. Insect tolerant transgenic tomato plants. Bio/Technology 5:807-813.

Fisk, H.J. 1996. The nuclear-targeting of foreign gene products as a strategy to enhance their stability. PhD diss. Univ. of California, Davis.

Flavell, R.B. 1994. Inactivation of gene expression in plants as a consequence of specific sequence duplication. Proc. Natl. Acad. Sci. USA 91:3490-3496.

Fujimoto, H., K. Itoh, M. Yamamoto, J. Kyozuka, and K. Shimamoto. 1993. Insect resistant rice generated by introduction of a modified $\delta$ endotoxin gene of Bacillus thuringiensis. Bio/Technology 11:11511155.

Hobbs, S.L.A., P. Kpodar, and C.M.O. DeLong. 1990. The effect of TDNA copy number, position and methylation on reporter gene expres- 
sion in tobacco transformants. Plant Mol. Biol, 15:851-864.

Höfte, H. and H.R. Whiteley. 1989. Insecticidal crystal proteins of Bacillus thuringiensis. Mirobiol. Rev. 53:242-255.

Holsters, M., D.D. Waele, A. Depicker, E. Messens, E.V. Montagu, and J. Schell. 1978. Transfection and transformation of Agrobacterium tumefaciens. Mol. Gen. Genet. 163:181-187.

Hood, E.E., G.L. Helmer, R.T. Fraley, and M. Chilton. 1986. The hypervirulence of Agrobacterium tumefaciens A281 is encoded in a region of pTiBo542 outside of T-DNA. J. Bacteriol. 168:1291-1301.

James, D.J., S. Uratsu, J. Cheng, P. Negri, P. Viss, and A.M. Dandekar. 1993. Acetosyringone and osmoprotectants like betaine or proline synergistically enhance Agrobacterium-mediated transformation of apple. Plant Cell Rpt. 12:559-563.

Jefferson, R.A. 1987. Assaying chimeric genes in plants: GUS gene fusion system. Plant Mol. Biol. Rpt. 5:387-405.

Kado, C.I., M.G. Heskett, and R.A. Schilperoort. 1972. Studies on Agrobacterium tumefaciens: Characterization of strains 1D135 and B6, and analysis of the bacterial chromosome, transfer RNA and ribosomes for tumor-inducing ability. Physiol. Plant Pathol. 2:47.

Koziel, M.G., G.L. Beland, C. Bowman, N.B. Carozzi, R. Crenshaw, L. Crossland, J. Dawson, N. Desai, M. Hill, S. Kadwell, K. Launis, K. Lewis, D. Maddox, K. McPherson, M.R. Meghji, E. Merlin, R. Rhodes, G.W. Warren, M. Wright, and S.V. Evola. 1993. Field performance of elite transgenic maize plants expressing an insecticidal protein derived from Bacillus thuringiensis. Bio/Technology 11:194-200.

Ludlum, C.T., G.W. Felton, and S.S. Duffey. 1991. Plant defenses: Chlorogenic acid and polyphenol oxidase enhance toxicity of Bacillus thuringiensis subsp. kurstaki to Heliothis zea. J. Chem. Ecol. 17:217-237.

MacIntosh, S.C., G.M. Kishore, F.J. Perlak, P.G. Marrone, P.G. Stone, T.B. Stone, S.R. Sims, and R.L. Fuchs. 1990. Potentiation of Bacillus thuringiensis insecticidal activity by serine protease inhibitors. J. Agr. Food Chem. 38:1145-1152.

McBride, K.E. and K.R. Summerfelt. 1990. Improved binary vectors for Agrobacterium-mediated plant transformation. Plant Mol. Biol. 14:269_ 276.

Murashige, T. andF. Skoog. 1962. A revised medium for rapid growth and bioassays with tobacco tissue cultures. Physiol. Plant. 15:473-497.

Palauqui, J. and H. Vaucheret. 1995. Field trial analysis of nitrate reductase co-suppression: A comparative study of 38 combinations of transgene loci. Plant Mol. Biol. 29:149-159.

Perlak, F.J., R.W. Deaton, T.A. Armstrong, R.L. Fuchs, S.R. Sims, J.T.
Greenplate, and D.A. Fischhoff. 1990. Insect resistant cotton plants. Bio/Technology 8:939-943.

Perlak, F.J., R.L. Fuchs, D.A. Dean, S.L. McPherson, and D.A. Fischhoff. 1991. Modification of the coding sequence enhances plant expression of insect control protein genes. Proc. Natl. Acad. Sci. USA 88:3324-3328.

Sugiura, A., R. Tao, H. Murayama, and T. Tomana. 1986. In vitro propagation of Japanese persimmon. HortScience 21:1205-1207.

Sutton, D.W., P.K. Havstand, and J.D. Kemp. 1992. Synthetic cryIIIA gene from Bacillus thuringiensis improved for high expression in plants. Transgenic Res. 1:228-236.

Tamura, M., R. Tao, and A. Sugiura. 1992. Highly stable regeneration from long-term cultures of Japanese persimmon callus. HortScience 27:1048.

Tao, R., T. Handa, M. Tamura, and A. Sugiura. 1994. Genetic transformation of Japanese persimmon (Diospyros kaki L.) by Agrobacterium rhizogenes wild type strain A4. J. Jpn. Soc. Hort. Sci. 63:283-289.

Tao, R. and A. Sugiura. 1992a. Micropropagation of Japanese persimmon (Diospyros kaki L.), p. 426-440. In: Y.P.S. Bajaj (ed.). Biotechnology in agriculture and forestry. vol. 18. High-tech and micropropagation 2. Springer-Verlag, Berlin.

Tao, R. and A. Sugiura. 1992b. Adventitious bud formation from callus cultures of Japanese persimmon. HortScience 27:259-261.

Tao, R., S.L. Uratsu, A.M. Dandekar. 1995. Relative virulence of Agrobacterium strains on persimmon (Diospyros kaki L.). Acta Hort. 392:171-178.

Tao, R., K. Yonemori, and A. Sugiura. 1991. High frequency plant regeneration from callus cultures derived from primordial leaves of adult Japanese persimmon and protoplast isolation from those callus lines. Acta Hort. 300:251-254.

Towbin, H.T., T. Staehelin, and J. Gordon. 1979. Electrophoretic transfer of proteins from polyacrylamide gels to nitrocellulose sheets: Procedure and some applications. Proc. Natl. Acad. Sci. USA 70:4350-4354.

Vaeck, M., A. Reynaerts, H. Höfte, S. Jansens, M. DeBeukeleer, C. Dean, M. Zabeau, M. van Montague, and J. Leemans. 1987. Transgenic plants protected from insect attack. Nature 328:33-37.

Vail, P.V., J.S. Tebbets, D.F. Hoffmann, and A.M. Dandekar. 1991. Responses of production and storage walnut pests to Bacillus thuringiensis insecticidal crystal protein fragments. Biol. Control 1:329-333.

Whiteley, H.R. and H.E. Schnepf. 1986. The molecular biology of parasporal crystal body formation in Bacillus thuringiensis. Annu. Rev. Microbiol. 40:549-576. 